\title{
Eutrophication and the disrupted nitrogen cycle
}

\author{
This article belongs to Ambio's 50th Anniversary Collection. Theme: Eutrophication
}

\author{
Michael Tedengren
}

Published online: 3 February 2021

After the Second World War, there was a global need for increased food production to feed a growing population, and new techniques to increase agricultural production were developed once the war was over. In the 1950s and 1960 s this led to "the third agricultural revolution" (or "the green revolution" as it was later called), and in 1970 one of the early innovators, the American scientist Norman Borlaug, received the Nobel peace prize "for saving billions of people from starvation". Key elements in this development were introduction of high-yield crop varieties, increased irrigation, and the use of pesticides and synthetic fertilizers, which significantly increased the availability of e.g. organic nitrogen in agricultural systems. A rough estimate suggests that the yearly global human creation of reactive nitrogen (basically all forms of nitrogen besides $\mathrm{N}_{2}$ ) has more than doubled since 1950, with more than a $70 \%$ increase just since 1990 (Galloway and Cowling 2021).

However, while the green revolution rapidly increased food production and contributed strongly to alleviate global malnutrition, the tremendous global increase in synthetic fertilizer use in agriculture, with subsequent leaking into water-ways and seeping into ground-water reservoirs also led to human health issues, eutrophicated watersheds and coastal waters, with anoxic deep water and subsequently diminished abundance and biodiversity of bottom fauna. These problems started to receive serious scientific attention and public awareness in the late 1970s and early 1980s, and the first warning signals came from well studied enclosed water basins like the Baltic Sea (e.g. Larsson et al. 1985; Elmgren 1989). However, it was also early realized that the environmental problems following increased nutrient loads from agrochemicals and other antrophogenic activities where of a global nature, since these chemically and biologically reactive nutrients are distributed around the globe via wind transport, land run-off and ocean currents (e.g. Caraco 1995; Galloway 1998), and affect not only aquatic ecosystems, but also terrestrial (e.g. Matson and Vitousek 1987).

In this Anniversary Collection, we highlight four innovative and highly cited Ambio papers (Elmgren 1989; Caraco and Cole 1999; Galloway and Cowling 2002; Matson et al. 2002), covering a period when the global problem of increased output of reactive nitrogen became generally acknowledged and science shifted focus from problem identification to mitigative actions and providing management decision-making advice. Elmgren (1989) described how eutrophication had changed energy flows in the total Baltic Sea ecosystem and discussed how it would likely change in the future, if not mitigated. Caraco and Cole (1999) modelled and analysed the human impact on nitrate transport to the oceans via the world's major rivers, and how nitrogen saturation could dramatically increase nitrogen export. Matson et al. (2002) discussed how effectively reactive nitrogen was retained in different systems and how the global atmospheric deposition of excess nutrient affects terrestrial ecosystems with different soils and vegetation characteristics. Finally, Galloway and Cowling (2002) gave an historic overview of changes in reactive nitrogen, sources and consequences, over the nineteenth and twentieth century, as well as an interesting and innovative outlook for the future.

The authors of all four original Ambio articles share with us the background of their early work and reflect on the significance of the featured papers when they were published, their impact today, and discuss where to go from here (Caraco 2021; Elmgren 2021; Galloway and Cowling 2021; Hall et al. 2021). Furthermore, in two invited perspectives, high profile researchers in this field reflect on the legacy of the original articles, how they helped us 
understand the global eutrophication issue and reframe policy targets regarding environmental impacts from reactive nitrogen, and also discuss coming challenges (Bonsdorff 2021; Melillo 2021).

Today we know much more about eutrophication and its consequences than 20 years ago. Successfully reduced emission of reactive nitrogen from transport and energy production systems has contributed to cleaner air and reduced the global emission from fossil fuel combustion to the environment, but the still increasing human use of antropogenic nitrogen compounds in food production and agriculture leads to cascading ecosystem effects, and poses a major environmental challenge for the twenty-first century. Some of the contributing authors point out that there is after all room for cautious optimism since mitigative actions, like improved sewage management and restoration of wetlands, have had local and regional effects. Therefore some ecosystems are in better shape with regard to eutrophication today than 20 years ago, although many problems remain to be solved.

Enjoy reading!

\section{REFERENCES}

Bonsdorff, E. 2021. Eutrophication - early warning signals, ecosystem-level and societal responses, and ways forward. 50th Anniversary Collection: Eutrophication. Ambio. Volume 50. https://doi.org/10.1007/s13280-020-01432-7.

Caraco, N.F. 1995. Influence of humans on phosphorus transfers to aquatic systems: A regional scale study using large rivers. In Phosphorus in the Global Environment. Phosphorus Cycles and Management, ed. H. Tiessen, 235-244. Wiley, New York.

Caraco, N.F. 2021. A tribute to tributaries: River studies elucidate links between human activity and nutrient export across a broad range of watersheds. 50th Anniversary Collection: Eutrophication. Ambio. Volume 50. https://doi.org/10.1007/s13280-02001462-1.
Caraco, N.F., and J.J. Cole. 1999. Human impact on nitrate export: An analysis using major world rivers. Ambio 28: 167-170.

Elmgren, R. 1989. Man's impact on the ecosystem of the Baltic Sea: Energy flows today and at the turn of the century. Ambio 18: 326-332.

Elmgren, R. 2021. Assessing human effects on the Baltic Sea ecosystem. 50th Anniversary Collection: Eutrophication. Ambio. Volume 50. https://doi.org/10.1007/s13280-020-01463-0.

Galloway, J.N. 1998. The global nitrogen cycle: Changes and consequences. Environmental Pollution 102 (S1): 15-24.

Galloway, J.N., and E.B. Cowling. 2002. Reactive nitrogen and the world: 200 Years of change. Ambio 31: 64-71.

Galloway, J.N., and Cowling E.B. 2021. Reflections on 200 years of nitrogen, 20 years later. 50th Anniversary Collection: Eutrophication. Ambio. Volume 50. https://doi.org/10.1007/s13280-02001464-z.

Hall, S.J., K.A. Lohse, and P.A. Matson. 2021. Globalization of nitrogen deposition and ecosystem response: A twenty-year perspective. 50th Anniversary Collection: Eutrophication. Ambio. Volume 50. https://doi.org/10.1007/s13280-020-01465-y.

Larsson, U., R. Elmgren, and F. Wulff. 1985. Eutrophication and the Baltic Sea - Causes and consequences. Ambio 14: 9-14.

Matson, P.A., and P.M. Vitousek. 1987. Cross-system comparison of soil nitrogen transformation and nitrous oxide fluxes in tropical forest ecosystems. Global Biogeochemical Cycles 1: 163-170.

Matson, P.A., K.A. Lohse, and S.J. Hall. 2002. The globalization of nitrogen deposition: Consequences for terrestrial ecosystems. Ambio 31: 113-119.

Melillo, J.M. 2021. Disruption of the global nitrogen cycle: A grand challenge for the 21st century. 50th Anniversary Collection: Eutrophication. Ambio. Volume 50. https://doi.org/10.1007/ s13280-020-01429-2.

Publisher's Note Springer Nature remains neutral with regard to jurisdictional claims in published maps and institutional affiliations.

Michael Tedengren $(\bowtie)$ Associate Professor, Director of Studies in Ecology and Marine Biology.

Address: Department of Ecology, Environment and Plant Sciences, Stockholm University, 10691 Stockholm, Sweden.

e-mail: michael.tedengren@su.se 


\section{Man's Impact on the Ecosystem of the Baltic Sea: Energy Flows Today and at the Turn of the Century}

The impact of Man on the Baltic ecosystem in the 20th century is summarized by estimating changes in major energy flows, expressed as organic carbon. Recent eutrophication has increased pelagic primary production by an estimated $30-70 \%$, and sedimentation of organic carbon by $70-190 \%$. Above the primary halocline, biomass and production of benthos have increased, while in the deep waters of the Baltic proper, oxygen deficiency has led to the loss of formerly important food chains over nearly $100000 \mathrm{~km}^{2}$ of bottom. The net result is an approximate doubling of macrobenthic production, but little increase in meiobenthic production. Zooplankton production is thought to have increased less than primary production, perhaps by about a quarter. Fish catches in the Baltic have increased more than tenfold, but this is considered to be due only partly to increased fish production caused by more food for fish. Increased fishing effort and the near extermination of fish-eating Baltic seals, through hunting and pollution, are likely to be about equally important. Today, the Baltic fishery requires about $10 \%$ of the primary production in the Baltic to produce its catches, whereas the remnant seal population needs less than $0.1 \%$. At the beginning of this century the fishery required about $1 \%$ and the marine mammals an estimated $5 \%$ of the primary production.

\section{INTRODUCTION}

The Baltic Sea is considered one of the most contaminated seas in the world (1). It is also one of the most thoroughly studied marine regions (2). One reason is that the ecosystem approach (3), aiming for an understanding of energy flow and regulation in the ecosystem, has been in use here for almost two decades. The Baltic is thus an ideal area for an attempt at summarizing the human impact on a marine ecosystem. This is done using energy flows, expressed as organic carbon, to integrate the effects of all kinds of human interference whether by pollution, harvesting or physical modification.

In this paper I first summarize recent reviews $(4,5)$ of chemical and biological long-term changes in the Baltic Sea inside the Danish straits (areas 1-5 in Fig. 1). A recent review of the flows of organic carbon in the Baltic $(6$, summarized in Table 1 ) is taken to represent the present. Based on what is known about the mechanisms of eutrophication and the influence of toxic pollutants in the Baltic, I then back-calculate the likely organic carbon flows at the turn of the century when human influence was still small. I finally compare the estimated ecosystem changes with the real long-term trends, to arrive at a summary of how Man has changed the Baltic ecosystem in this century. This is a rash under- taking, and given the approximate nature of most of the figures in Table 1 , the resulting estimates are very uncertain. I still believe it a worthwhile effort, not least because it forces us to acknowledge the deficiencies in our present knowledge of the mechanisms whereby Man changes marine ecosystems.

\section{LONG-TERM CHANGES IN THE} BALTIC ECOSYSTEM

Physical and Chemical Changes

The recorded changes in physical driving forces, such as freshwater input and wind stress (summarized in 7,8), are not large enough to explain the deterioration in oxygen conditions noted in the deep water of the Baltic proper and the Gulf of Finland over the last 40 years or so. Oxygen concentrations have declined also in the deep waters of the Bothnian Sea, but are still satisfactory for both demersal fish and benthos. The decline in deep-water oxygen concentrations is now generally considered to be due mainly to increased oxygen consumption in the waters in and below the halocline $(3,8)$. Shaffer $(9)$ estimated that an increase in consumption of about $60 \%$ was needed to explain the decline in oxygen levels in the deep water of the Baltic proper. He considered that this was due mainly to an increase in the amount of organic matter settling out from the euphotic zone, an increase brought about by eutrophication. However, the anthropogenic discharge of organic matter into the Baltic is probably less than $10^{6}$ ton $\mathrm{C} \cdot \mathrm{yr}^{-1}$, much less than the internal photosynthetic production of about $50 \cdot 10^{6}$ ton $\mathrm{C} \cdot \mathrm{yr}^{-1}(6)$. The increased sedimentation must thus be due overwhelmingly to an increased production within the Baltic itself.

Since the turn of the century, the Baltic phosphorus load has increased about eightfold, and the nitrogen load about fourfold (10). This increase must have taken place largely after World War II and at an accelerated pace after about 1955-1960 (11). In the last decade, the nitrogen load from Sweden has increased only slowly, while the phosphorus load has decreased (12), and the nitrogen concentration in precipitation seems to be holding steady, at least over Sweden $(13,14)$.

Nutrient concentrations in the water column have increased in virtually all parts of the Baltic (15). This is particularly evident in late winter concentrations of the inorganic fractions, but the increase is also noted for annual averages of total phosphorus and total nitrogen in many areas. In the Baltic proper, winter nitrate concentrations in the surface water have increased two- to threefold since the late 1960 s, with a similar increase in winter phosphate concentrations since the $1950 \mathrm{~s}$. In many areas, winter phosphate concentrations have levelled off or decreased slightly since the late 1970 s, when the last stagnation period in the Baltic proper started, whereas nitrate concentrations have continued to increase (15). The one clearly anomalous area is the Bothnian bay, where primary production is limited by phosphorus, unlike most of the Baltic (4). Here no increase has been recorded in phosphate or total phosphorus, even though the nitrate levels have increased at least as much as in other parts of the Baltic (15).

\section{Biological Changes}

Based on the increased nutrient availability in the Baltic in recent decades, one would expect major biological changes. It has, however, been surprisingly difficult to demonstrate such changes convincingly. Few observational series exist that have used identical methods with a sufficient 


\section{Human Impact on Nitrate Export: An Analysis Using Major World Rivers}

We developed a simple model that related $\mathrm{NO}_{3}$ export to point-source $\mathrm{N}$ loading and nonpoint source $\mathrm{N}$ loads from chemical fertilizers and $\mathrm{NO}_{\mathrm{y}}$ deposition and tested it at the global scale using data from 35 large rivers with a global distribution. The model explained well $\left(r^{2}>0.8\right)$ the nearly 1000 -fold variation in $\mathrm{NO}_{3}$ export from different regions of the world. The model suggests that human activity is the dominant control of $\mathrm{NO}_{3}$ export even though less than 20 of the $100 \mathrm{Tg} \mathrm{N} \mathrm{yr} r^{-1}$ added to land in fertilizer and $\mathrm{NO}_{\mathrm{y}}$ deposition is at present exported from rivers as $\mathrm{NO}_{3}$. Watershed export to rivers may increase in the future due to either increased loads to the watershed or decreased watershed retention. Simple models, coupled with continued measurements of $\mathrm{NO}_{3}$ in rivers, will be of use in interpreting these regional changes.

\section{INTRODUCTION}

In many estuaries, and in coastal seawater, concentrations of available $\mathrm{N}$ limit primary production $(1,2)$. Thus, factors that increase $\mathrm{N}$ loading can have serious or critical impacts on the functioning of coastal ecosystems $(3,4)$. One important way in which $\mathrm{N}$ is loaded to the coast is in river flow (5). These rivers obtain their $\mathrm{N}$ from diffuse inputs from the watersheds (nonpoint sources) and by inputs directly to the river (point sources) (6). Humans have increased $\mathrm{N}$ loading to terrestrial systems through a variety of processes including the manufacture of fertilizer and the use of high temperature internal combustion engines (7). The nature of the linkage between increased human loading of $\mathrm{N}$ to watersheds and the output of that $\mathrm{N}$ to coastal waters is not straightforward. The export of $\mathrm{N}$ applied to terrestrial systems depends on a myriad of factors including hydrology, geology (slope, soil type), and human alteration of landscape by forest clearing and wetland destruction (8). Given this complexity, it is not surprising that there have been few attempts to study the variation and controls of $\mathrm{N}$ loading to coastal waters at the regional to global scale (but see 9-11). Rather, much of the research has been focused on process-level studies at more manageable scales (12-15). Nitrogen pollution, however, is a regional to global-scale problem and we need to understand the linkage between $\mathrm{N}$ input and $\mathrm{N}$ output at the appropriate scale.

The study of rivers offers an opportunity to examine the effects of anthropogenic loading on export as chemical constituents in these rivers serve as integrative measures of land-water exchange at the watershed scale (16-19). Further, for very large rivers, the watershed encompasses entire regions, and regional export can then be compared to regional anthropogenic loading. These comparisons allow insights into both which human activities are important to export across regions, and estimates of regional-scale retention (20).

In this paper, we attempt to determine the importance of various human activities which influence $\mathbf{N}$ export at the regional to global scale using data from the world's major watersheds. In particular, we focus on the impacts of humans on increased $\mathrm{N}$ loading to terrestrial systems through fertilizer application and $\mathrm{NO}_{y}$ deposition, and the impact of point sources (sewage) added directly to rivers. Prior studies on large rivers with global distribution have shown that both $\mathrm{NO}_{3}$ and $\mathrm{PO}_{4}$ export are related to human population density in the watershed $\left(r^{2} \sim 0.5\right)(9,20)$. Additionally, for $\mathrm{PO}_{4}$, a simple model that included point source

and nonpoint inputs gave a better prediction of river export than did human population alone, and allowed evaluation of the importance of various human activities in controlling $\mathrm{P}$ export in different regions of the world (20). Further, this model gives insights into the magnitude and controls of watershed retention at the regional scale. In this study, we use a similar approach considering $\mathrm{NO}_{3}$ export.

\section{APPROACH}

Our data set includes 35 large river systems with worldwide distribution (Table 1). For each of these systems, there are relatively good estimates of average annual $\mathrm{NO}_{3}$ export. We can compare these export values to those predicted from a simple loading model:

$$
\begin{aligned}
& \text { modeled } \mathrm{NO}_{\text {3export }}=\left(\mathrm{R}_{\text {exporr }}\right)^{\mathrm{x}} \\
& {\left[\text { Point Inputs }+(\mathrm{WS} \text { expor })^{\mathrm{x}}(\mathrm{WS} \text { Inputs })\right] .}
\end{aligned}
$$

where $\mathrm{R}_{\text {export }}$ and $\mathrm{WS}_{\text {export }}$ are the export coefficients (the fraction of loaded N that is exported) from rivers and watersheds, respectively. Point Inputs and WS Inputs are the amounts of $\mathrm{N}$ that is loaded to the river and watershed, respectively. These loading terms and the $\mathrm{N}$ export by rivers are expressed as average loading over the area of the watershed $\left(\mathrm{kg} \mathrm{N} \mathrm{km}^{-2} \mathrm{yr}^{-1}\right)$. For point

Table 1. Characteristics of 35 rivers used in $\mathrm{N}$ export model. Runoff is water runoff in meters per year. Urban population is in humans per $\mathbf{k m}^{2}$ of watershed and fertilizer load, $\mathrm{No}_{y}$ input and River Export are all in $\mathrm{kg}$ of $\mathrm{N}$ per $\mathrm{km}^{2}$ of watershed per year.

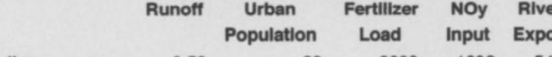

$\begin{array}{lrrrrr} & & \text { Population } & \text { Load } & \text { Input } & \text { Export } \\ \text { Adige } & 0.58 & 68 & 2889 & 1093 & 541 \\ \text { Amazon } & 0.78 & 1 & 14 & 150 & 33\end{array}$

$\begin{array}{lllrrr}\text { Amazon } & 0.78 & 1 & 14 & 150 & 33 \\ \text { Columbla } & 0.37 & 7 & 323 & 100 & 62\end{array}$

Danube

Delaware

Glama

Huanghe

Hudson

Kazan and Back

Mackenzle

Magdalena

Mekong

Meuse

Mississippi

Murray-Darling

Niger

Nile

Orange

Orinoco

Parana

Para

Po

Rhine

Rhone

St. Lawrence

Susquehanna

Thames

Tiber

Uruguay

Vistula

Volga

Yolga

Yangtze

Yukon

Zaire

Zambezl

0.25

0.60

0.47

0.53 


\section{Reactive Nitrogen and The World: 200 Years of Change}

This paper examines the impact of food and energy production on the global $\mathrm{N}$ cycle by contrasting $\mathrm{N}$ flows in the late- $19^{\text {th }}$ century with those of the late- $20^{\text {th }}$ century. We have a good understanding of the amounts of reactive $\mathrm{N}$ created by humans, and the primary points of loss to the environment. However, we have a poor understanding of nitrogen's rate of accumulation in environmental reservoirs, which is problematic because of the cascading effects of accumulated $\mathrm{N}$ in the environment. The substantial regional variability in reactive nitrogen creation, its degree of distribution, and the likelihood of increased rates of reactive$\mathrm{N}$ formation (especially in Asia) in the future creates a situation that calls for the development of a Total Reactive Nitrogen Approach that will optimize food and energy production and protect environmental systems.

\section{INTRODUCTION}

The late-18th century- $\mathrm{N}$ discovered.

The late-19th century-natural $\mathrm{N}$ fixation discovered.

The late-20th century-anthropogenic $\mathrm{N}$ fixation exceeded natural terrestrial $\mathrm{N}$ fixation.

Nitrogen is the very stuff of life. It constitutes a major part of the nucleic acids that determine the genetic character of all living things and the enzyme proteins that drive the metabolic machinery of every living cell. Triple-bonded nitrogen gas $\left(\mathrm{N}_{2}\right)$ makes up nearly $80 \%$ of the total mass of the Earth's atm osphere. To most organisms, this huge reservoir of $\mathrm{N}$ is not biologically available. Before $\mathrm{N}$ can be used by most plants, animals, insects, and microorganisms, the triple bonds of $\mathrm{N}_{2}$ molecules must be broken and the resulting single- $\mathrm{N}$ atoms must be bonded chemically with one or more of 3 other essential nutrient elements oxygen and/or hydrogen through $\mathrm{N}$-fixation processes and carbon through $\mathrm{N}$-assimilation processes (1).

Breaking the triple bonds within the $\mathrm{N}_{2}$ molecule is an energyrequiring reaction. In nature, fixation of $\mathrm{N}_{2}$ is accomplished mainly by certain unique microorganisms that have developed the special metabolic machinery necessary to produce biologically active reduced forms of nitrogen such as ammonia, amines, and am ino acids - the structural constituents of proteins and nucleic acids (2). These specialized organisms include a few freeliving bacteria and blue-green algae, and also certain symbiotic bacteria that have developed special metabolic relationships with the roots of leguminous crop plants such as soybeans, clover, and $\mathrm{N}$-fixing trees such as alder. Oxidative fixation of gaseous $\mathrm{N}_{2}$ leads to production of reactive oxidized forms of $\mathrm{N}$. Oxidative fixation of $\mathrm{N}$ also takes place in nature, but only in high-temperature natural processes such as lightning.

In the pre-human world, biological nitrogen fixation was the dominant means by which new reactive nitrogen (Nr) (3) was made available to living organisms. The total amount of $\mathrm{Nr}$ that circulated naturally among various compartments of the atmosphere and the biosphere of the Earth was quite small. Thus, the biodiversity and intricate webs of relationships found in nature evolved as a result of intensive competition among many different life forms - most of them evolving under N-limited conditions.

During the last 2 centuries, human involvement with $\mathrm{N}$ began with discovery of $\mathrm{N}$ as an element (late- $18^{\text {th }}$ century). This led to the discovery of biological nitrogen fixation (late- $19^{\text {th }}$ cen- tury), and eventually to the human dominance of the global rate of $\mathrm{N}$ fixation (late- $20^{\text {th }}$ century). This paper presents an assessment of the impact of humans on the biogeochemical cycle of $\mathrm{N}$ due to the enhanced creation of reactive-N. Following a historical overview, this paper discusses the changes in N-mobilization rates due to human activities, the resultant changes in the distribution fluxes to waters and the atmosphere, and an assessment of the environmental consequences of these changes. The paper concludes with an overview of regional differences in human alteration of the $\mathrm{N}$ cycle, casts an eye toward the future and presents the case for developing a Total Nr Approach for management of $\mathrm{N}$.

\section{HIST ORICAL CONT EXT}

Two hundred years span the time from discovery of $\mathrm{N}$ as an element to the present time of human dominance in $\mathrm{Nr}$ creation. Over that period, the global human population increased from $\sim 0.85$ billion to $\sim 6.2$ billion. This section presents significant discoveries regarding $\mathrm{N}$ in the context of a growing human population (Fig. 1). Unless otherwise noted, historical information is taken from Smil (4).

Nitrogen was discovered in the late $18^{\text {th }}$ century through the work of several early chemists-Scheele (1742-1786, Sweden), Rutherford (1749-1819, Scotland), Lavoisier (1743-1794, France). It was formally named 'nitrogene', by the French scientist, Chaptal (1756-1832). Nitrogen's role in crop production was not recognized until the mid- $19^{\text {th }}$ century, initially by Boussingault (1802-1887) and then more thoroughly by von Liebig (1803-1873), who developed the theory of nutrient limitation in plant productivity. Near the end of the $19^{\text {th }}$ century, Hellriegel (1831-1895) and Wilfarth (1853-1904) discovere that microbial communities could extract nonreactive $\mathrm{N}_{2}$ from the atmosphere and convert it into a useable form-biological nitrogen fixation (BNF).

Less than 50 years after $\mathrm{N}$ was first identified as an essential nutrient for all plants and animals it was also discovered that the growing demand for food by increasing human populations was exceeding known sources. In 1898, Sir William Crookes, president of the British Association for the Advancement of Science, stated: "All England and all civilized nations stand in deadly peril of not having enough to eat" due to the increasing demands for food and the lack of biologically available nitro-

Figure 1. Global population trends $(36,53)$ with key dates for the discovery of $\mathrm{N}$ as an element in the periodic table and its role in various biogeochemical processes. Also shown is an estimate of the annual production of $\mathrm{Nr}$ by the Haber-Bosch process.






\section{The Globalization of Nitrogen Deposition: Consequences for Terrestrial Ecosystems}

\begin{abstract}
The sources and distribution of anthropogenic nitrogen $(\mathrm{N})$, including $\mathrm{N}$ fertilization and $\mathrm{N}$ fixed during fossil-fuel combustion, are rapidly becoming globally distributed. Responses of terrestrial ecosystems to anthropogenic $\mathrm{N}$ inputs are likely to vary geographically. In the temperate zone, long-term $\mathrm{N}$ inputs can lead to increases in plant growth and also can result in over-enrichment with $\mathrm{N}$, eventually leading to increased losses of $\mathrm{N}$ via solution leaching and trace-gas emissions, and in some cases, to changes in species composition and to ecosystem decline. However, not all ecosystems respond to $\mathrm{N}$ deposition similarly; their response depends on factors such as successional state, ecosystem type, $\mathrm{N}$ demand or retention capacity, land-use history, soils, topography, climate, and the rate, timing, and type of $\mathrm{N}$ deposition. We point to some of the conditions under which anthropogenic impacts can be significant, some of the factors that control variations in response, and some areas where uncertainty is large due to limited information.
\end{abstract}

\section{INTRODUCTION}

Human activities have more than doubled inputs of nitrogen $(\mathbb{N})$ to terrestrial ecosystems worldwide (1). Until recently, most of this increase was focused in the developed regions of the world. With fertilizer consumption (2), fossil-fuel emissions ( 3 ), and biomass burning (4) rapidly increasing in less developed regions, sources and distribution of anthropogenic $\mathrm{N}$ now occur globally (5), as does the deposition of N.

Anthropogenic $\mathrm{N}$ additions to temperate ecosystems have been shown to affect a wide range of ecosystem properties and processes, especially when inputs are large and continuous. For example, $\mathrm{N}$ additions can alter net primary production (NPP) and nutrient cycling (6), interact with elevated carbon dioxide $\left(\mathrm{CO}_{2}\right)$ (e.g. 7), cause significant reductions in biological diversity (8), and influence rates of $\mathrm{N}$ transfer via hydrologic loss (9). As discussed in Rabalais (10), increased nitrate leaching from N-saturated ecosystems also drives acidification and eutrophication and alters biodiversity in downstream freshwater and marine systems (e.g. 11).

Many of the observed responses of terrestrial systems to $\mathrm{N}$ deposition can be understood within the context of "nitrogen saturation" $(12,13)$, a conceptual model that was developed using knowledge derived from temperate-forest ecosystems and that has been applied to changes in ecosystem functioning that occur as $\mathrm{N}$ additions relieve $\mathrm{N}$ limitation to biological activity. In general, the $\mathrm{N}$ saturation model predicts that N-limited systems initially retain anthropogenic $\mathrm{N}$ by using it for plant and microbial growth as well as accumulation in biomass and soil organic matter. At some point, however, inputs of $\mathrm{N}$ begin to exceed the biotic (and perhaps abiotic) demands for $\mathrm{N}$ within the ecosystem, and the system is predicted to lose its $\mathrm{N}$ retention capacity. As the capacity to retain $\mathrm{N}$ is exceeded, excess $\mathrm{N}$ is available to be lost from the system via solution losses and gas fluxes. For example, nitrate leaching has been identified as a primary sign of $\mathrm{N}$ saturation in $\mathrm{N}$-limited temperate forests if it occurs at a significantly higher rate than "background" lev- els, immediately after $\mathrm{N}$ additions without a significant temporal lag period, or aseasonally in a naturally seasonal ecosystem (14). Furthermore, the model predicts eventual decreases in production that can occur due to cation losses, nutrient imbalances, or increased plant susceptibility to other stresses, such as frost, ozone, or insect attack.

Not all terrestrial ecosystems, however, respond to elevated $\mathrm{N}$ inputs in these ways. In recent years, the accumulation of information about the effects of $\mathrm{N}$ deposition in a variety of ecosystems, primarily in North America and Europe, has allowed analysis of the range of responses among terrestrial ecosystems, as well as the factors that contribute to that dramatic range (e.g. 15 ). In addition, the globalization of $\mathrm{N}$ deposition raises questions concerning consequences of anthropogenic $\mathrm{N}$ for ecosystems outside the well-studied regions. Because tropical forests cover $17 \%$ of the Earth's surface and make up $40 \%$ of the global NPP (16), even small alterations in major biogeochemical cycles there can have global significance. Relatively young soils common to temperate and boreal ecosystems differ markedly from highly-weathered tropical systems; while $\mathrm{N}$ generally limits productivity in temperate ecosystems $(17)$, phosphorus $(\mathrm{P})$ or calcium (Ca), removed from soils through intense weathering processes most likely limit production in humid tropical forest and savanna ecosystems (18). In many of these systems, $\mathrm{N}$ may already be a nutrient in excess, so many tropical humid forests may be naturally $\mathrm{N}$ saturated (19).

In this paper, we summarize some of the direct and indirect effects of increasing anthropogenic $\mathrm{N}$ inputs on ecosystem processes in temperate ecosystems and compare some of these effects to predicted responses in tropical ecosystems. We draw on a number of excellent reviews on the issue of $\mathrm{N}$ deposition and saturation in terrestrial ecosystems that have been published in the past several years (for example, $6,8,15,20-22$ ). Thus, we do not attempt a thorough review, but rather we point to some of the conditions under which anthropogenic impacts can be significant, some of the factors that contribute to variations in response, and some of the areas where uncertainty is large due to limited information.

\section{N RETENTION IN ECOSYSTEMS AND EFFECTS ON PRODUCTION}

Terrestrial plant growth over much of Earth, and particularly in temperate and boreal ecosystems, is primarily limited by $\mathrm{N}$, as demonstrated by numerous fertilization studies where $\mathrm{N}$ additions cause an increase in NPP until growth is limited by other resources (23). If chronic, long-term deposition of $\mathrm{N}$ into terrestrial ecosystems increases $\mathrm{N}$ availability, then it should also cause at least a temporary increase in NPP as plants respond with increased $\mathrm{N}$ uptake and growth. Forests in Europe and North America are generally growing faster now than earlier this century, and at least part of that increase has been attributed to increased atmospheric $\mathrm{N}$ inputs $(24,25)$. Similarly, N-fertilization experiments in the northeastern United States and Europe have shown increased NPP with $\mathrm{N}$ additions, at least in the first few years, depending largely on the $\mathrm{N}$ status of the ecosystem (20). The level and extent of $\mathrm{N}$ input, however, clearly matters in terms of response. In her analysis of production data from stud- 